\title{
Cytogenetic Observations in Cultured Lymphocytes from Patients with Down's Syndrome and Measles
}

\author{
MaKato Higurashi ${ }^{[22]}$ \\ Department of Maternal and Child Health, School of Health Sciences, Faculty of Medicine, \\ University of Tokyo, Tokyo, Japan \\ Takashi Tamura and Toshiniko Nakatake \\ Division of Hematology, Kyorin Medical Technological College, Kyorin, Japan
}

\section{Extract}

Chromosomes were studied in 72-hr lymphocyte cultures from 11 patients with Down's syndrome and 8 hematologically and karyotypically normal control subjects before and after measles infection.

The number of breaks per cell in patients with Down's syndrome after measles infection was $0.191 \pm 0.073$, which was significantly greater than the number of breaks before infection $(0.040 \pm 0.020)$ and which was also significantly greater than the number of breaks in control children with measles $(0.046 \pm 0.024)$. Therefore, chromosomes of cells of patients with Down's syndrome were significantly more sensitive to measles infection than those of control subjects.

Statistical assessments were made on randomness and nonrandomness of breakage distribution in chromosome groups and arms. Excess breaks were found to occur in the long arms of $\mathrm{B}$ and $\mathrm{D}$ group chromosomes.

\section{Speculation}

Patients with Down's syndrome show more chromosomal breaks after virus infection than do normal control subjects. The susceptibility of patients with Down's syndrome to neoplasia may allow us to recognize trisomic cells to be particularly cancer prone.

\section{Introduction}

Since the findings by Nichols [12] of a high frequency of chromosome breakage in cultured lymphocytes from patients with measles, cytogenetics has yielded much information which demonstrates the significant relation between viral infection and chromosome disturbances in human cells in vitro.

Down's syndrome is a chromosomal disorder with an increased risk of malignant disease [7, 9, 16]. Cultured lymphocytes from children with Down's syndrome are significantly more radiosensitive than those of control subjects [14]. To gain further insight into the relation between Down's syndrome and leukemia, we have compared the incidence of chromosomal breakage in lymphocytes from children with Down's syndrome and those from normal children before and after measles infection.

From the evidence presented in this paper, we conclude that chromosomes of cultured lymphocytes from children with Down's syndrome are significantly more 
Table $I$. Details of cases with Down's syndrome and frequency of chromosomal aberrations

\begin{tabular}{|c|c|c|c|c|c|c|}
\hline Case & $\frac{\text { Age }}{\text { mo yr }}$ & Sex & Breaks/cell before infection ${ }^{1}$ & $\begin{array}{l}\text { Interval after } \\
\text { onset of rash, } \\
\text { days }\end{array}$ & Breaks after infection ${ }^{1}$ & $\begin{array}{l}\text { Breaks/cell after } \\
\text { infection }\end{array}$ \\
\hline$I(K T)$ & 8 & Male & $0.03(100)$ & 2 & $32(100)$ & 0.32 \\
\hline $2(K O)$ & 9 & Male & $0.06(100)$ & 2 & $28(100)$ & 0.28 \\
\hline $3(Y H)$ & 9 & Female & $0.07(100)$ & 1 & $17^{2}(75)$ & 0.22 \\
\hline $4(T I)$ & 3 & Male & $0.04(100)$ & 2 & $10(80)$ & 0.125 \\
\hline $5(J T)$ & 1 & Female & $0.01(100)$ & 4 & $9(100)$ & 0.09 \\
\hline $6(M H)$ & 5 & Female & $0.04(100)$ & 5 & $17(100)$ & 0.17 \\
\hline $7(N M)$ & 8 & Male & $0.07(100)$ & 1 & $18(100)$ & 0.18 \\
\hline $8(K Y)$ & 2 & Female & $0.02(100)$ & 6 & $9(95)$ & 0.095 \\
\hline $9(M K)$ & 3 & Female & $0.03(100)$ & 3 & $16(100)$ & 0.16 \\
\hline $10(S K)$ & 4 & Male & $0.02(100)$ & 1 & $21(100)$ & 0.21 \\
\hline $11(H N)$ & 1 & Male & $0.05(100)$ & 3 & $24(100)$ & 0.24 \\
\hline (Mean total) & & & 0.040 & & $201 \quad(1,050)$ & 0.191 \\
\hline
\end{tabular}

${ }^{1}$ Number of cells examined appears in parentheses.

${ }^{2}$ Number includes 1 dicentric.

sensitive to viral infection than those from normal children.

\section{Materials and Methods}

Peripheral blood samples were obtained from a group of patients with Down's syndrome both before and during measles infection. Two groups of normal children were studied as controls, inasmuch as it was impossible to obtain specimens from the same children before and after infection.

\section{Patients with Measles}

Blood samples were obtained from 11 patients with regular trisomy 21 who ranged from 8 months-9 years of age (Table I) and from 8 control children with normal karyotypes and normal hematologic findings, 7 months- 5 years of age (Tables II and III). Measles was diagnosed in most cases by clinically typical manifestations such as Koplik's spots, the appearance of skin rash, and others. Serologic tests for diagnosis were included only for those children with Down's syndrome in whom clinical findings of measles were questionable. In the control group, cases with atypical measles were excluded. The intervals from the onset of rash to the days of samples ranged from 1-6 days. No individual had received either $\mathrm{x}$-rays for diagnosis or chloramphenicol therapy in the recent past.

\section{Patients before Measles Infection}

The frequency of chromosomal aberrations in patients with Down's syndrome before measles infection
Table II. Details of normal control subjects and frequency of chromosomal aberrations before measles infection

\begin{tabular}{|c|c|c|c|c|c|}
\hline \multirow{2}{*}{ Case } & Age & \multirow{2}{*}{ Sex } & \multirow{2}{*}{$\begin{array}{l}\text { No. } \\
\text { cells } \\
\text { exam- } \\
\text { ined }\end{array}$} & \multirow{2}{*}{ Breaks } & \multirow{2}{*}{$\begin{array}{l}\text { Breaks/ } \\
\text { cell }\end{array}$} \\
\hline & mo yr & & & & \\
\hline$I(Y I)$ & 5 & Female & 100 & 2 & 0.02 \\
\hline $2(K W)$ & 2 & Male & 100 & 3 & 0.03 \\
\hline $3(A M)$ & 6 & Female & 100 & 2 & 0.02 \\
\hline $4(H S)$ & 11 & Male & 100 & 2 & 0.02 \\
\hline $5(K K)$ & 3 & Female & 100 & 1 & 0.01 \\
\hline $6(E M)$ & 4 & Female & 100 & 3 & 0.03 \\
\hline $7(J I)$ & 2 & Male & 100 & 2 & 0.02 \\
\hline $8(T A)$ & 11 & Male & 100 & 1 & 0.01 \\
\hline (Mcan total) & & & 800 & 16 & 0.020 \\
\hline
\end{tabular}

Table III. Details of normal control subjects and frequency of chromosomal aberrations after measles infection

\begin{tabular}{|c|c|c|c|c|c|c|}
\hline Case & $\frac{\text { Age }}{\text { mo yr }}$ & Sex & $\begin{array}{l}\text { Inter- } \\
\text { val } \\
\text { after } \\
\text { onset } \\
\text { of } \\
\text { rash, } \\
\text { days }\end{array}$ & $\begin{array}{l}\text { No. } \\
\text { cells } \\
\text { exam- } \\
\text { ined }\end{array}$ & Breaks & $\begin{array}{c}\text { Breaks/ } \\
\text { cell }\end{array}$ \\
\hline$l(T H)$ & 5 & Female & 1 & 100 & 6 & 0.06 \\
\hline $2(N H)$ & 3 & Female & 1 & 98 & 2 & 0.020 \\
\hline $3(N W)$ & 9 & Female & 3 & 95 & 9 & 0.095 \\
\hline $4(G K)$ & 7 & Male & 2 & 100 & 6 & 0.060 \\
\hline $5(M S)$ & 5 & Male & 5 & 100 & 3 & 0.030 \\
\hline $6(T O)$ & 4 & Maie & 3 & 100 & 5 & 0.05 \\
\hline $7(N N)$ & 5 & Female & 2 & 100 & 4 & 0.04 \\
\hline $8(Y S)$ & 1 & Male & 3 & 100 & 7 & 0.07 \\
\hline (Mean total) & & & & 793 & 40 & 0.046 \\
\hline
\end{tabular}

was obtained from samples taken previously for cytogenetic diagnosis. Eight hundred cells from eight control children, 5 months- 6 years of age, who were hemato- 
logically and cytogenetically normal, were used as noninfected controls.

Blood samples were cultured for $72 \mathrm{hr}$, including a terminal incubation with colchicine, by a minor modification of Moorhead's method [10]. In most test and control cultures, metaphases from at least 100 lymphocytes were studied; when this was not possible, a minimum of 75 suitable metaphases/culture were examined. All metaphases were investigated by direct $\mathrm{mi}$ croscopic examination and records were kept of the microscope stage position of the cell, the chromosome

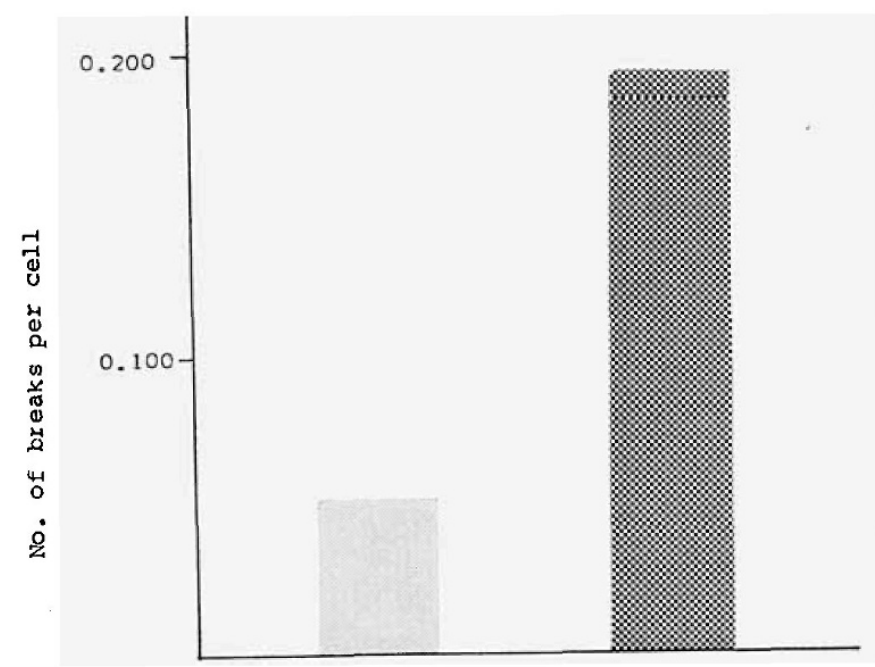

Fig. 1. Comparison of the number of breaks per cell after measles infection in normal control subjects (left bar) and in patients with Down's syndrome (right bar). Number of cells examined: normal control subjects, 793; patients with Down's syndrome, 1,050 .

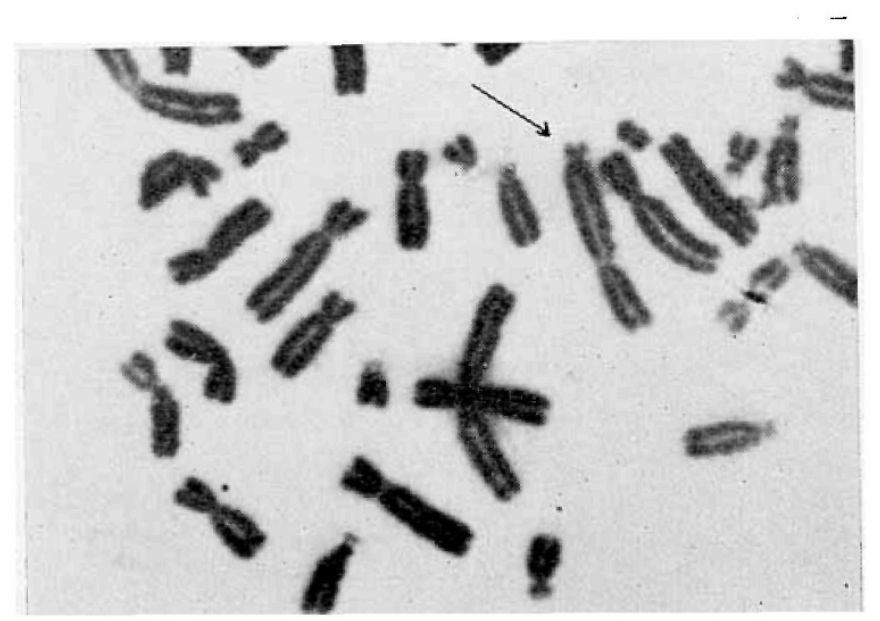

Fig. 2. Arrow indicates a metaphase with a dicentric (case 3 of Down's syndrome). count, and aberrations present. Cells in mitosis were used for detailed study if they appeared to be unbroken with well defined chromosomal morphology at high magnification. Photographs for karyotype or analyses on the prints were made from all cells in which chromosomal abnormalities were recognized. Drawings of part of some metaphases were made to study overlapping chromosomes. Inasmuch as chromatid- and chromosome-type breaks were common, they were tentatively grouped in the same category, being accepted as one break on scoring frequencies of breaks. The number of breaks for dicentrics and rings was obtained by adding twice the number of two-hit aberration. Chromatid gaps or visual discontinuities of chromatin without displacement were recorded separately but were excluded from the calculations.

\section{Results}

Chromosomal Aberrations in Lymphocytes from $\mathrm{Pa}$ tients with Down's Syndrome and from Control Subjects (Tables I and II)

Chromosomal aberrations in patients with Down's syndrome were more frequent than in control subjects, but the difference was not statistically significant. Before measles infection, the number of breaks per cell in patients with Down's syndrome was 0.040 compared with 0.020 in control subjects. A few chromatid- and chromosome-type breaks were observed in cultured lymphocytes from the individuals with Down's syndrome and from the control subjects, but dicentrics, fragments, and interchanges were seldom seen in either group.

Chromosomal Aberrations in Lymphocytes from $\mathrm{Pa}$ tients Infected with Measles (Tables $I$ and III, Fig. l)

In lymphocytes from patients infected with measles virus, the number of breaks per cell in Down's syndrome was significantly higher than in control subjects $(P<0.01)$. The number of breaks per cell in patients with Down's syndrome ranged from 0.09 to 0.32 with an average value of 0.191 , whereas the range was from 0.020 to 0.095 with an average of 0.046 in the control subjects. The most frequent chromosomal aberrations observed in the infected specimens from both groups were chromosome breaks involving both chromatid and chromosome types, but one metaphase with dicentrics was found in 1,050 cells from patients with Down's syndrome (Fig. 2). 
Comparson of Chromosomal Aberrations in Patients before and after Measles Infection

Controls (Fig. 3). No significant differences were found in the frequency of chromosomal aberrations in the control groups before and after measles infection. The number of breaks per cell before infection was 0.020 and, after infection, 0.046 .

Down's syndrome (Fig. 4). A significant increase was found in the number of breaks per cell from patients with Klown's syndrome with measles compared with pre-inrection cultures $(P<0.01)$. The number of breaks per cell after infection was 0.191 , whereas that before infection was 0.040 .

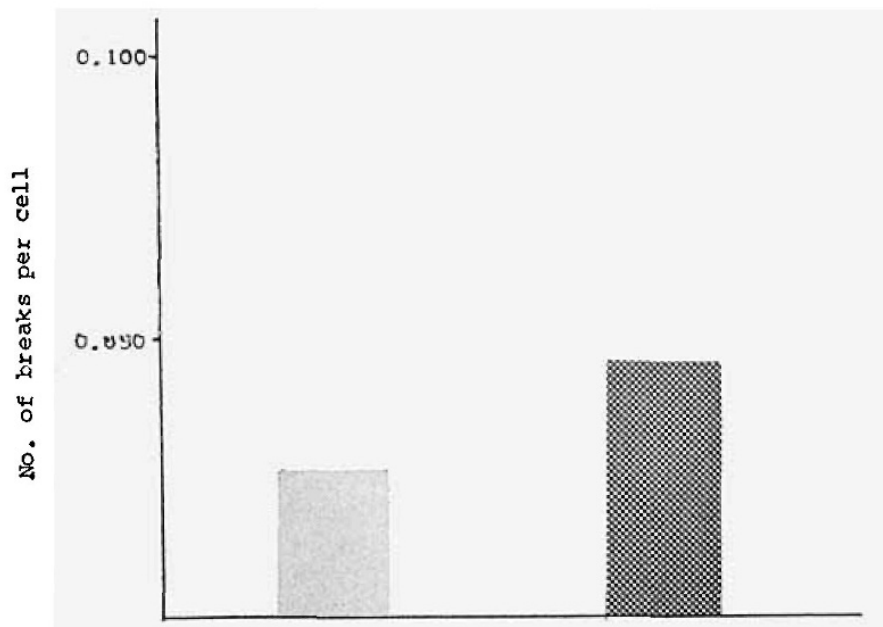

Fig. 3. Comparison of the number of breaks per cell in control subjects before (left bar) and after (right bar) infection. Number of cells examined: before infection, 800; after infection, 793 .

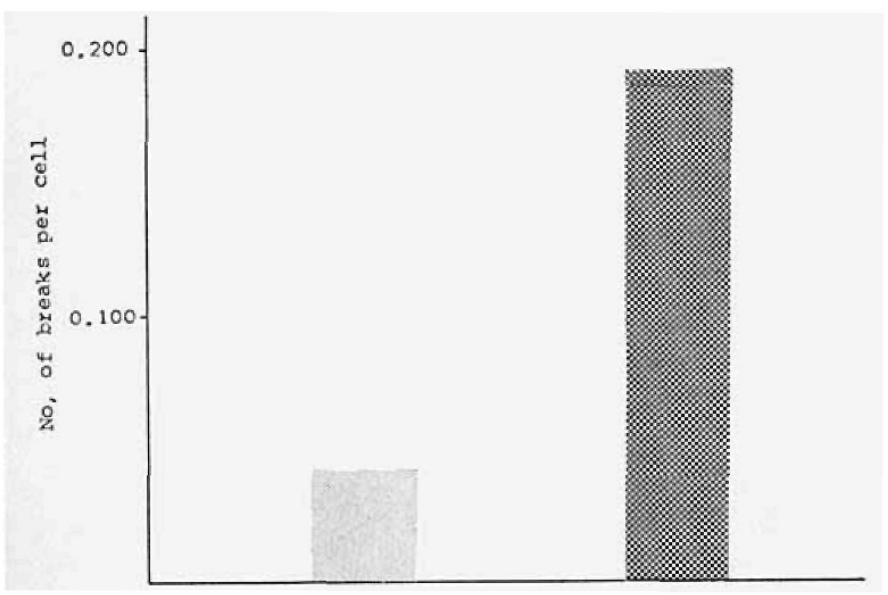

Fig. 4. Comparison of the number of breaks per cell in chromosomes of patients with Down's syndrome before (left bar) and after (right bar) infection. Number of cells examined: before infection, 1,100; after infection, 1,050.
Table IV. Distribution of breaks in each chromosome group

\begin{tabular}{crrr}
\hline Chromosome group & Observed & Expected & Chi-square \\
\hline A 1 & 18 & 16.86 & 0.08 \\
A 2p & 6 & 6.12 & 0.00 \\
q & 12 & 9.56 & 0.62 \\
A 3 & 16 & 13.10 & 0.64 \\
B p & 4 & 6.48 & 0.95 \\
q & 24 & 17.06 & 2.82 \\
C p & 24 & 26.76 & 0.28 \\
q & 46 & 48.82 & 0.16 \\
D p & 1 & 2.96 & 1.30 \\
q & 24 & 16.62 & 3.28 \\
E 16 & 8 & 6.00 & 0.67 \\
E 17-18p & 2 & 3.48 & 0.63 \\
E 17-18q & 6 & 7.80 & 0.42 \\
F & 6 & 9.20 & 1.11 \\
G 21--22p & 0 & 1.66 & 1.66 \\
21-22q & 4 & 4.88 & 0.16 \\
Y & 0 & 3.64 & 3.64 \\
\hline
\end{tabular}

Distribution of Breaks in Chromosome Groups (Table
IV)

In control subjects, breaks in cultured lymphocytes were too infrequent to determine their distribution in different chromosome groups. In cells from patients with Down's syndrome, however, breaks were considerably more frequent, and their distribution was studied. The observed numbers of breaks in a given chromosome were compared with those expected from the relative length of chromosome available for breaks. It was assumed that breaks occur equally in all portions of each chromosome. The largest excess of breaks above the expected number was in the long arm of $\mathrm{D}$ group chromosomes $(\mathrm{Dq})$ followed by the long arm of $\mathrm{B}$ group chromosomes $(\mathrm{Bq})$.

\section{Discussion}

A high incidence of chromosome breaks in cultured leukocytes from certain virus-infected patients was reported by some investigators $[1,12]$ but was not found by others $[3,8,11,18]$. It seems likely that the discrepancy in the findings was caused by the different frequency of chromosome breaks due to different times for sampling of cells for culture [1] and by differences in susceptibility to virus infection in each case [3].

The present results showed that the number of chromosome breaks in cultured lymphocytes from normal control subjects did not increase significantly after measles infection compared with those before infection. On the other hand, in patients with Down's syndrome, the number of breaks per cell was significantly 
higher after measles infection than before infection and also was significantly higher than in the control group after infection. The same persons may be compared before and after infection in the control groups as in the Down's syndrome groups. This is even more important since there is a great range in the frequencies of chromosome breaks, even in the trisomic group. We tried to determine whether there was any relation between the severity of the disease and the number of chromosome breaks observed or not, but no relation was found. This heterogeneity in response is in itself interesting.

Chromosomes of cells from Down's syndrome were reported to be significantly more radiosensitive than those of control subjects $[5,15]$. Furthermore, patients with Fanconi's anemia, Bloom's syndrome, and ataxiatelangiectasia, who have an increased risk of malignant diseases as in Down's syndrome, were reported also to be significantly more radiosensitive than control subjects $[5,6]$. We are planning to study effects of measles virus on the chromosomes of normal and Down's cells in vitro. In addition, the present findings of increase chromosomal sensitivity toward virus infection in cells with trisomy 21 may be comparable to the findings of Todaro and Martin [19] of increased susceptibility of trisomic cells to transformation by SV40 virus. The connection between the increased chromosomal sensitivity of cells with trisomy 21 toward virus infection and the susceptibility of patients with Down's syndrome to neoplasia may allow us to recognize trisomic cells to be particularly cancer prone.

An excess of chromosome breaks in the long arms of chromosome 2 in cultured leukocytes was reported in patients with measles by Nichols et al. [13]. An excess of breaks in chromosomes 4-5 was found in specimens from patients with infectious hepatitis and with chicken pox [2]. The present results showed that the difference between the observed and the expected values for breakage in one particular chromosome was not significant, although a slight excess of chromosome breaks was observed in the long arms of chromosome $\mathrm{D}$ and chromosome B in Down's syndrome after measles infection. The site of chromosome breaks during viral infection seemed to depend on a variety of factors such as the type of virus, individual sensitivity to virus, and the conditions of cell culture.

\section{Summary}

Chromosomes were studied in 72-hr lymphocyte cultures from 11 patients with Down's syndrome and 8 hematologically and karyotypically normal control subjects before and after measles infection.

The most frequent chromosomal aberrations observed in the infected specimens from both groups were chromosome breaks involving both chromatid and chromosome types, but one metaphase with dicentrics was found in 1,050 cells from Down's syndrome.

The number of breaks per cell in Down's syndrome after measles infection was $0.191 \pm 0.073$; this was significantly greater than $0.040 \pm 0.020$, before infection, and was also significantly greater than $0.046 \pm$ 0.024 in control children with measles. Therefore, chromosomes of cells from patients with Down's syndrome were significantly more sensitive to measles infection than those from control subjects.

The present results showed that the difference between the observed and the expected values for breakage in one particular chromosome was not significant, although a slight excess of chromosome breaks was observed in the long arms of chromosomes $\mathrm{D}$ and $\mathrm{B}$ in Down's syndrome after measles infection.

\section{References and Notes}

1. Aula, P.: Chromosome breaks in leukocytes of chicken pox patients. Preliminary communicaiton. Hereditas, 49, 451 (1963).

2. Aula, P.: Virus-associated chromosome breaks. Amer. Acad. Sci. Ser. A Biol., 89: 1 (1965).

3. Harnden, D. G.: Cytogenetic studies on patients with virus infection and subjects vaccinated against yellow fever. Amer. J. Hum. Genet., 16: 204 (1964).

4. Higurashi, M., And Conen, P. E.: In vitro chromosomal radiosensitivity in Fanconi's anemia. Blood, 38: 336 (1971).

5. Higurashi, M., And Conen, P. E.: In vitro chromosomal radiosensitivity in patients and in carriers with non-Down's syndrome karyotypes. Pediat. Res., 6: 514 (1972).

6. Higurashi, M., and Conen, P. E.: In vitro chromosomal radiosensitivity in "chromosomal breakage syndromes." Cancer (in press).

7. KRIVIT, W., AND Good, R. A.: Simultaneous occurrence of mongolism and leukemia: Report of nationwide survey. $J$. Dis. Childhood, 94: 289 (1957).

8. Makino, S., Aya, T., AND Ikeuchi, T., et al.: A further study of chromosomes in cultured leukocytes from aseptic meningitis patients. Proc. Jap. Acad., 42: 270 (1966).

9. Miller, R. W., and Fraument, J. F., JR.: Down's syndrome and neonatal leukemia. Lancet, $i i$ : 404 (1968).

10. Moorhead, P. S., Nowell, P. C., and Mellman, W. J., et al.: Chromosome preparations of leukocytes cultured from human peripheral blood. Exp. Cell Res., 20: 613 (1960).

11. Morx, M.: Some aspects of chromosome aberrations in leukocyte cultures from measles patients. Kromosoma, 77: 2510 (1969).

12. Nichols, W. W.: Relationships of virus, chromosomes and carcinogenesis. Hereditas, 50: 53 (1963).

13. Nichols, W. W., Leven, A., Aula, P., and Norrby, E.: Extreme chromosome breakage induced by measles virus in different in vitro system. Hereditas, 51: 380 (1964). 
14. Sasaki, M. S., ANd Tonomura, A.: Chromosomal radiosensitivity in Down's syndrome. Jap. J. Human Genet., 14: 81 (1969).

15. Sasaki, M. S., Tonomura, A., and Matsubara, S.: Chromosomal constitution and its bearing on the chromosomal radiosensitivity in man. Mutat. Res., 10: 617 (1970).

16. Schunk, G. J., AND LehMan, W. L.: Mongolism and congenital leukemia. J. Amer. Med. Ass., 155: 250 (1954).

17. Penrose, L. S.: A note on the mean measurements of human chromosomes. Ann. Hum. Genet., 28: 195 (1964).

18. Tanzer, J., Srortchkov, Y., ANd Harel, P., et al.: Chromosomal abnormalities in measles. Lancet, ii: 1070 (1963).

19. Todaro, G. J., and Martin, G. M.: Increased susceptibility of Down's syndrome fibroblasts to transformation by SV40. Proc. Soc. Exp. Biol. Med., 124: 1232 (1967).
20. We wish to thank Professor T. Takatsu, Director of the Department of Pediatrics, Kyorin University, and Professor $\mathrm{N}$. Kobayashi, Director of the Department of Pediatrics, University of Tokyo, for their help in arranging the sampling, and also Dr. P. E. Conen and Dr. J. M. Sturgess, Department of Pathology and Department of Biochemistry, The Research Institute, The Hospital for Sick Children, Toronto, Canada, for their advice on English expression.

21. This research was supported by grants from the Scientific Research Fund of the Ministry of Health and Welfare, Japan.

22. Requests for reprints should be addressed to: Makoro $\mathrm{HI}_{-}$ Guroshi, M.D., Department of Maternal and Child Health, School of Health Sciences, Faculty of Medicine, University of Tokyo, Bunkyo-ku, Tokyo, Japan.

23. Accepted for publication January 24, 1973. 